\title{
Exploring the Usefulness of e-Resources for Engineering College Teachers and Scholars for their Academic and Research Activities - A Study
}

\author{
R. M. Puttaswamy \\ Library and Information Centre \\ B N M Institute of Technology, India \\ E-mail: swamyrmp@gmail.com
}

\author{
M. Krishnamurthy* \\ Department of Library \& Information Science \\ Mangalore University, India \\ E-mail: mkrishna_murthy@hotmail.com
}

\begin{abstract}
The All India Council for Technical Education (AICTE), an apex body of controlling technical education in India, has made mandatory subscription of e-Resources to all its Engineering College Libraries. This policy has directly helped the teaching community, research scholars, and student's paternity, which has benefits for their teaching, research activities, and curriculum, respectively. This study emphasizes the usefulness of e-Resources among the teachers and scholars of engineering colleges in the Bangalore region under Visvesvaraya Technological University (VTU), Belgaum, Karnataka. Survey methodology has been used as the basic research tool for data collection with the help of questionnaires. 866 teaching faculties in VTU were selected randomly on the basis of willingness of users who access the e-Resources for their academic and research activities in the survey. The survey results were tabulated and analyzed with descriptive statistics methods using the SPSS 20 software package. The findings reveal that e-resources are useful for engineering college teachers and scholars for their academic and research activities.
\end{abstract}

Keywords: e-Resources, research activity, teachers, research scholars, academic, engineering colleges

\section{Open Access}

Accepted date: February 11, 2014

Received date: July 30, 2013

*Corresponding Author: M. Krishnamurthy Professor

Department of Library \& Information Science

Mangalore University, India

E-mail: mkrishna_murthy@hotmail.com 


\section{INTRODUCTION}

The rapid growth and extensive reach taken place in the field of Information and Communication Technology (ICT) has paved the way for scholarly communications work. Today, we are living in a place where technology has dominated. In recent years the internet and web have become more popular and necessary tools for every individual due to their affordable cost with more benefits. This trend has motivated libraries to go ahead to avail the benefits in building their collections to provide technology-based e-content to academic communities. The libraries are the center of attraction in college campuses to provide e-Resources to their users to keep abreast on the latest development in their fields. The libraries are the center of research activities from where research starts and research ends and also the hub of the latest technological developments. This trend would definitely boost research activities and brings radical changes for quality academic work across the country. Indeed, technology has become such an integral part of our lives that it has enabled ways for users to make use of e-Resources on their desktops, laptops, and palm tops too.

\section{VISVESVARAYA TECHNOLOGICAL UNIVERSITY AT A GLANCE}

The Visvesvaraya Technological University (VTU), Belgaum, Karnataka, India, was established on April 1, 1998 by an act called the VTU Act 1994 for the purpose of imparting quality technical education and promotes research in the field of Engineering, Technology, and Allied Sciences in the state of Karnataka. As per provision, Visvesvaraya Technological University can affiliate only Engineering colleges that offer Bachelor of Engineering/Bachelor of Technology courses. The institutions who wish to offer Postgraduate Programs (PG) and Master of Technology/Master of Business Administration/Master of Computer Application programs have to start with Bachelor of Engineering/Bachelor of Technology programs. Visvesvaraya Technological University (VTU) is one of the biggest technological universities in India, having 204 colleges affiliated to it with undergraduate courses with 28 disciplines and postgraduate (PG) programs in 71 disciplines. The intake at the undergraduate (UG) level is about 67,100 students, and at the postgraduate level it is about 12,666 students. There are 2305 departments recognized as research centers in addition to the Master of Business Administration (MBA) Program. The jurisdiction of the university is spread over the Karnataka state having four regional centers at Bangalore, Belgaum, Gulbarga, and Mysore. Over 98 engineering colleges exists in the Bangalore region itself which is considered the silicon city of India.

\section{DEFINITION OF E-RESOURCE}

Libraries have transformed into digital and virtual environments, where books and journals have changed into e-books and e-journals. Electronic resources are easily accessible in remote areas.

An electronic resource may be defined as:

A resource which requires computer access or any electronic product that delivers a collection of data, be it text referring to full text bases, electronic journals, image collections, other multimedia products, and numerical, graphical, or time based as a commercially available title that has been published with an aim to being marketed. These may be delivered on CDROM, on tape, via internet, and so on.

"E-Resources are the resources available in electronic form such as e-Books, e-Journals, e-Newspapers, and bibliographic databases, e-Images, e-Sound, and music collections".

"The term e-Resources are used to describe all of the information products that a library provides through a computer network. This includes electronic books, journals, bibliographic databases, and library websites pages" (Prabhushankar, Arokyamary, \& Ramasesh, 2012).

\section{TYPES OF E-RESOURCES}

The emergence of various distribution systems of electronic journals from CD-ROM was the first step to local data loading, where publishers provided im- 
age and text data directly to libraries (Barnes, 1997). Different types of e-resources are available both in open access and commercial forms.

On-line e-Resources: Online e-Resources can be classified into resources which are directly connected to the internet or web, such as e-Books, e-Journals, e-Mail, G-mail, SMS/MMS, (Short Message Service/ Multi Message Service), e-Library, e-Forum, e-Learning courses, e-Shops, e-Dictionaries, search engines, Meta search engines, and websites.

Off-line e-Resources: Off-line e-Resources are categorized as sources which are not directly linked with internet or web, viz. CD-ROM based e-Resources, off-line e-Books, off-line, e-Dictionaries, Microsoft Office applications, Power Point Presentations, training software (mouse training), e-Prompter, Stenography, PDF (Portable Document Format) converter, and e-Resources on mobile devices. These resources may be accessed through various tools like library catalogs, library websites, library blogs, and OPAC/ EPAC (Online Public Access Catalogue/Electronic Public Access Catalogue).

\section{GROWTH OF E-RESOURCES}

Technology has presented itself in all areas of life and the use of information and communication technology (ICT) is commonplace in the $21^{\text {st }}$ century. Libraries use ICT for better service and satisfying diverse user needs. The libraries in engineering colleges are drifting towards an e-world, i.e. building e-libraries which have become a necessity for users who are "tech savvy" and always need information on their finger-tips. In other words we call them "customized e-information packages" to reach the end users anywhere and anytime. The concept of people going to libraries has changed as now libraries are going to people. This is because of technology and e-resources invading the library arena. Engineering libraries have to change and integrate technology into their systems and become more vibrant centers full of facilities. (Bankapur, et al., 2012).

Down the ages libraries too have adopted the changes in collection development. Now is a transition period for libraries. They are going from traditional printed materials collections to becoming libraries with their resources in digital form. With the onset of the Information and Communication Technology (ICT), the publishing industry and libraries have entered a fascinating period. Collections which are in electronic form can be retrieved over networks, sitting in any part of the globe. Since most of the traditional and magnetic resources are giving way to resources in electronic form, libraries are striving towards giving better services to their patrons including services such as Inter Library Loans and Current Awareness Services and Selective Dissemination of Information by using Information Communication Technology (ICT), which would help them in expanding their knowledge (Prabhushankar, Arokyamary, \& Ramasesh, 2012).

\section{OBJECTIVES}

The usefulness of e-Resources by faculty members for their academic activities and scholars for research work is highly discussed in academic circles. In this regard, the reference and use of electronic information and resources by engineering college teachers and research scholars to assess their specific information needs, along with the impact of ICT tools/applications, are the pertinent issues for this study. Thus, the present study consists of the following objectives:

1 . To study the preferred source of information among engineering college teachers and research scholars;

2. To identify their preferred type of e-Resources;

3. To know the frequency of access pertaining to various tasks;

4. To find out the quality of e-content retrieved;

5. To explore the challenges faced by users while accessing e-resources;

6. To study the impact of e-Resources and services in their academic and research activities.

\section{SCOPE, LIMITATIONS, AND METHODOLOGY}

The scope of the present study possesses certain limitations as the study is limited to the teachers and scholars working in various colleges under Visvesvaraya Technological University (VTU) in Karnataka 
only. Faculty members who are teaching undergraduate courses and postgraduate courses, and research scholars who have undertaken research work as well as teaching, were considered for the study as the sample frame. Only teachers and scholars working in the engineering colleges of Bangalore region, which comprises six districts in Karnataka State in India such as Bangalore Rural, Bangalore Urban, Ramanagar, Tumkur, Kolar, and Chikkaballapur, were considered. The total survey population of 866 was taken on the basis of availability of users during the time of the survey. The total number of users surveyed was based on random selection and categorized as Professors, Associate Professors, Assistant Professors, and Research scholars working in various departments of the selected engineering colleges under Visvesvaraya Technological University, Karnata$\mathrm{ka}$. The data was collected through survey methods with the help of a structured questionnaire. Accessibility and availability issues regarding the information were discussed with experts, and professors and the questions proposed by them were included in the questionnaires prepared for the final research study.

The data collected was analyzed with descriptive statistics methods using the SPSS 20 software package and presented in the form of tables for the goal of a clear understanding of the survey results.

\section{LITERATURE REVIEW}

The survey results on browsing of e-Journals by engineering faculty by Bennett, et al., (2010) indicate that, engineering faculty still use Table of Contents (ToC) and journal browsing to support current awareness and other information-seeking needs. The authors obtained data showing that engineering faculty still apparently pays attention to journal names and patterns of use among engineering departments. They highlighted the results to show some distinct patterns across the academic ranks of Assistant Professors, Associate Professors, and Professors. The respondent's ages correlate with their activities, but the authors settled instead for an assumption of general correlation of age, experience or habit, and academic rank. Perhaps rank is as strong an indicator of browsing behavior as is age, since the faculties of the same rank are engaged in similar research behaviors. Assistant Professors are still finessing their research focuses and assessing the place of their research within their disciplines. Mid-career Associate Professors are the most likely to have highly-focused research interests and to be aware of related work conducted by others. Late careers Professors are more likely to acknowledge the universe of research beyond their core awareness.

Ansari, et al., (2010) have surveyed the use of electronic resources among academics at the University of Karachi. Their study finds that, electronic resources are the best means of getting current and up-todate information. They observed that academicians use these electronic resources, but due to networking problems and lack of training they are not properly used. As per their observations, a majority of academicians are quite satisfied with electronic resources even though they regard them as less reliable. However, they consider electronic resources produced by an authentic organization or website to be authentic and reliable. Electronic resources are mostly used for research and lecture preparation. The use of scholarly electronic journals at the Indian Institute of Science was studied by Moghaddam, et al., (2008). The results of the study suggest that, the library network with the availability of significant numbers of electronic journals at the Indian Institute of Science (IISc.) has been successful. Their results suggests that 24-hours free access to electronic resources at the user's desktop leads to increased acceptance and use of scholarly electronic journals. This service needs to be maintained and continued in future at the Indian Institute of Science. This successful service can be used as model for other institutions in India as well as other developing countries. The study of Engel, et al., (2011) explores the information-seeking habits of engineering faculty from twenty public research universities. The authors investigated how frequently engineering faculty seek or access information, how they keep abreast of current developments in the field and find less recent journal articles, how often they visit the library in person, and how important library services and resources are in meeting their information needs. The responses from survey participants confirmed the findings of other studies that electron- 
ic access to current and archived scholarly journals and internet resources are important in meeting their needs. It was proved that further research on engineering faculty must be conducted to answer additional questions. Also, their observations raise the question, do the information-seeking behaviors of academic engineering faculty mirror the behavior of researchers in other disciplines, or do they more closely mirror that of their peers in engineering corporate environments? In this context, further research will help address these questions and assist librarians in fulfilling the core library mission of supporting the research and teaching needs of academic engineering faculty.

Rahiman, et al., (2011) have conducted a study on information seeking behavior of students of engineering colleges in and around Coimbatore, revealing that, the library remains the predominant primary source among the students, as it is continuously being depended on by young engineering students. The authors quoted an interesting finding that the information seeking processes of students is dominated by their visit to library. Their study also shows that libraries and management should focus on adding more projects, theses, online resources, CD's and DVD's, since a sizeable number of students feel that these resources are slightly sufficient or insufficient.

A study assessing the information-seeking behavior of Computer Science and Engineering faculty by Tucci, (2011) affirmed that computer scientists and engineering faculty at TCNJ (The College of New Jersey) are ahead of other disciplines in desiring change and have advance information-gathering habits. The author noted the changes caused by replacing print journals with online-only versions of the journals, developing new interlibrary loan and acquisition policies and processes, and subscribing to a major engineering and computer science resource (IEEE Explore), but even more important is initiating a dialogue with faculty via the focus groups. Much work remains to be done to continue to adapt to the changing information environment. To continue this dialogue and help faculty members assimilate and discover new information sources, librarians must integrate themselves so that they can add value and save time.

\section{FINDINGS AND DISCUSSIONS}

The results of the study reveal, as shown in Table 1 , that, 496 (57.50\%) out of 866 respondents working as teachers in various engineering colleges under Visvesvaraya Technological University in Karnataka state are Assistant Professors 134 (15.50\%) are Associate Professors, 166 (19\%) are working in areas like research, and only 70 (8\%) are Professors.

Table 1. Category of Respondents

\begin{tabular}{l|c|c}
\hline \multicolumn{1}{c|}{ Designation } & No. of respondents & Percentage \\
\hline Professor & 70 & 08.00 \\
\hline Associate Professor & 134 & 15.50 \\
\hline Assistant Professor & 496 & 57.50 \\
\hline Others (Research scholar) & 166 & 19.00 \\
\hline Total & 866 & 100.00 \\
\hline
\end{tabular}

It is evident from the above Table 2, that, 818 (94.50\%) out of 866 of the respondents who are working as teachers in engineering colleges under Visvesvaraya Technological University, Karnataka use online/e-Resources. Only 48 (5.50\%) of the teachers do not use online/e-Resources.

Table 2. Awareness on Use of Online/e-Resources

\begin{tabular}{c|c|c}
\hline $\begin{array}{c}\text { Use of online / } \\
\text { e-Resources }\end{array}$ & No. of Respondents & Percentage \\
\hline Yes & 818 & 94.50 \\
\hline No & 48 & 05.50 \\
\hline Total & 866 & 100.00 \\
\hline
\end{tabular}

\subsection{Preferred Place and Tools for Accessing Information}

The place and tools for accessing information differs between users on the basis of their needs, convenience, and availability of the information sources for them. It can be noted from Table 3, that, the most preferred place of information is their college library (64\%), department (62\%), and home $(47 \%)$ respectively. The above results (Table 3$)$ clear- 
ly shows that 'College Library' is the most popular place of information among the maximum number of college teachers and research scholars due to easy availability and accessibility (i.e. with the help of library assistants). The study also reveals (Table 3) that the most preferred tools for locating e-Resources are search engines (67\%), followed by library websites (33\%).

Table 3. Preferred Place of Search and Tools Used to Locate e-Resources

\begin{tabular}{l|c|c}
\hline \multicolumn{3}{c}{ Place of search for e-Resources } \\
\hline Place of search & Respondents & Percentage \\
\hline College Library & 552 & $64.00 \%$ \\
\hline Department & 533 & $62.00 \%$ \\
\hline Home & 408 & $47.00 \%$ \\
\hline \multicolumn{2}{|c|}{ Tools used to locate e-Resources } \\
\hline Details & Respondents & Percentage \\
\hline Search Engine & 576 & $67.00 \%$ \\
\hline Library Websites & 290 & $33.00 \%$ \\
\hline Total & 866 & $100.00 \%$ \\
\hline
\end{tabular}

\subsection{Most Useful and Preferred Types of E-Resources for Teaching and Research}

The internet enables users to access vast amounts of information to be independently retrieved by users at anytime from anywhere in the world. Teachers and scholars can benefit themselves with several e-Resource portals available. According to the survey results (Table 4), 506 respondents (58\%) prefer to use IEEE (Institute of Electrical and Electronics Engineers) portals, 291 respondents (34\%) prefer to use Elsevier, 276 respondents (32\%) prefer Springer, 196 (23\%) prefer ASME, and 177 respondents (20\%) prefer J-Gate. Teachers and scholars working in engineering colleges prefer to use certain resources for their day-to-day work. The present survey findings (Table 4), indicate that the majority of users, i.e. 818 (94\%) prefer e-journals, 811 (93\%) prefer e-books, 765 (88\%) prefer online references, 747 (86\%) prefer library networks, 742 (85\%) prefer library networks/
EPAC, $722(83 \%)$ prefer open access, and $718(82 \%)$ prefer to use electronic theses. The results reveal that the majority of users in all the surveyed engineering colleges access the above resources as they provide access to 'current up-to-date and wider range of information' for them related to their academic/research work.

Table 4. Most Useful e-Resources and Preferred e-Resource Portals

\begin{tabular}{l|c|c}
\hline \multicolumn{3}{|c}{ Preferred e-Resource Portals } \\
\hline Publishers & Respondents & Percentage \\
\hline IEEE & 506 & $58.00 \%$ \\
\hline Elsevier & 291 & $34.00 \%$ \\
\hline Springer & 276 & $32.00 \%$ \\
\hline ASME & 196 & $23.00 \%$ \\
\hline J-Gate & 177 & $20.00 \%$ \\
\hline McGraw-Hill & 176 & $20.00 \%$ \\
\hline Most useful resources for teaching and research \\
\hline Details & Respondents & Percentage \\
\hline e-Journals & 818 & $94.00 \%$ \\
\hline e-Books & 811 & $93.00 \%$ \\
\hline Online Reference & 765 & $88.00 \%$ \\
\hline Library networks & 747 & $86.00 \%$ \\
\hline Library Website/ EPAC & 742 & $85.00 \%$ \\
\hline Open access & 722 & $83.00 \%$ \\
\hline Electronic Thesis & 718 & $82.00 \%$ \\
\hline
\end{tabular}

\subsection{Purpose and Frequency of Access to Various Tasks and Time Spent}

Teachers and scholars need to access e-Resources for getting up to date information which helps them to complete various tasks. Table 5 reveals that the majority of teachers/scholars prefer to access e-resources for getting the latest information for their lectures (80\%), consultancy work (50\%), research work (40\%), and for professional development (38\%). 
The study also reveals that 385 (44.5\%) teachers/ scholars spend 1 to 2 hours daily in their library, 186 (21.60\%) spend half- an-hour daily, and 139 (16\%) spend 2 to 3 hours daily accessing e-resources. 111 teachers/scholars spend more than 4-hours accessing library e-resources.

Table 5. Purpose and Frequency of Access

\begin{tabular}{l|c|c}
\hline \multicolumn{3}{|c}{ Average time spent in library } \\
\hline Details & Respondents & Percentage \\
\hline Up to $1 / 2$ hour & 186 & $21.60 \%$ \\
\hline 01-02 hrs. & 385 & $44.50 \%$ \\
\hline 02-03 hrs. & 139 & $16.00 \%$ \\
\hline 03-04 hrs. & 45 & $05.00 \%$ \\
\hline More than 4 hrs. & 111 & $13.00 \%$ \\
\hline Total & 866 & $100.00 \%$ \\
\hline & Purpose of access & \\
\hline Details & Respondents & Percentage \\
\hline For Lectures & 689 & $80.00 \%$ \\
\hline Consultancy work & 432 & $50.00 \%$ \\
\hline Research works & 350 & $40.00 \%$ \\
\hline Professional & 328 & $38.00 \%$ \\
\hline
\end{tabular}

\subsection{Experience of Disadvantages in Using / Accessing e-Resources}

Even though e-resources provide access to a large amount of information for teachers/scholars, there are various barriers faced by these users while accessing e-resources. The study findings (Table 6) show that 'Copyrights issues' is the major barrier faced during accessing resources by 686 (79\%) respondents, with compatibility between formats (73\%), readability with $(72 \%)$, diverse data formats (71\%), and acceptability (70\%) as other barriers while accessing e-resources. The 'Complexity' of the content available in accessing e-Resources is a common issues faced by a majority of users.
Table 6. Experience of Disadvantages in Using e-Resources

\begin{tabular}{l|c|c}
\hline \multicolumn{2}{l}{ Experience of disadvantage in using e-Resources } \\
\hline Details & Respondents & Percentage \\
\hline Copyright issues & 686 & $79.00 \%$ \\
\hline $\begin{array}{l}\text { Compatibility between } \\
\text { formats }\end{array}$ & 630 & $73.00 \%$ \\
\hline \begin{tabular}{l} 
Readability \\
\hline $\begin{array}{l}\text { Use of diverse data } \\
\text { formats }\end{array}$
\end{tabular} & 614 & $72.00 \%$ \\
\hline Acceptability & 610 & $71.00 \%$ \\
\hline
\end{tabular}

\subsection{Problems Faced While Accessing e-Re- sources}

E-Resources are accessed for different purposes by different categories of users on the basis of their academic/professional needs and requirements. Even though e-Resources provides large amounts of information, there are various problems faced by users during access. The study findings (Table 7) shows that lack of infrastructure facilities (40\%) are a major problem in most of the college libraries. Lack of sufficient self-help guides (38\%) and lack of information on use of e-resources (35\%) are other problems faced in college libraries.

Table 7. Problems Faced While Accessing e-Resources

\begin{tabular}{l|c|c}
\hline \multicolumn{2}{c}{ Problems faced while accessing e-Resources } \\
\hline Details & Respondents & Percentage \\
\hline $\begin{array}{l}\text { Lack of availability of } \\
\text { computer terminals }\end{array}$ & 344 & $40.00 \%$ \\
\hline Lack of self-help guides & 326 & $38.00 \%$ \\
\hline $\begin{array}{l}\text { Lack of information } \\
\text { on use of e-Resources }\end{array}$ & 300 & $35.00 \%$ \\
\hline
\end{tabular}

\section{CONCLUSIONS AND SUGGESTIONS}

It can be concluded that the information landscape is changing swiftly with the progression in technology and the prolific growth of electronic resources. 
Electronic resources promote and advance teaching and learning and also qualitative research. It is no doubt that e-Resources play an important role in the day-to-day life of teachers and scholars working in university colleges as their use helps them in preparing for their lectures, consultancy work, research work, and for their professional development. College libraries and departments are the preferred place for accessing e-resources. The electronic resources mainly preferred by teachers and scholars in college libraries include e-journals, e-books, online resources, library networks, library Websites/EPAC (Electronic Public Access Catalog), open access, and electronic theses. The most preferred e-resource portals by teachers and scholars are IEEE (Institute of Electrical and Electronics Engineers), Elsevier, Springer, ASME (Association of Mechanical Engineers), J-Gate (Electronic gateway to global journal), and McGraw-Hill publishers. Teachers and scholars face various disadvantages while accessing e-resources, like copyrights issues, incompatibility between formats, diverse data formats, readability, and acceptability. While accessing e-Resources the major problems faced by them are the lack of sufficient infrastructure facilities and self-help guides at their college libraries.

Keeping in view of the above results, it is suggested that the librarians or library managers should facilitate their libraries effectively, so as to provide quality contents to their users with convenient ways to find and access them properly. Access to e-Resources is becoming important for teachers and scholars in university colleges; therefore libraries should emphasize useful e-Resources for their benefit. Today libraries and their users rely heavily on electronic resources and databases for their information needs and requirements, and therefore, it is essential that these resources are made accessible to users along with other materials. As the libraries primary task is to meet the information needs of all users, librarians should aim to bridge the current information gap concerning accessibility of the various electronic resources.

\section{ACKNOWLEDGEMENTS}

The authors sincerely acknowledge their thanks to both reviewers and editors for their kind suggestions, comments, and necessary recommendations to improve and standardize this article.

\section{REFERENCES}

Ansari, M. N., \& Zuberi, B. A. (2010). Use of electronic resources among Academics at the University of Karachi. Library Philosophy and Practice, 385.

Bachalapur, M. M. (2012). Use of e-resources at Kalpataru Institute of Technology, Tiptur: A survey. Trends in Developing and Managing e-Resources in Libraries, 140-145.

Bankapur, V. M., Chowdappa, N., \& Mulla, K. R. (2012). Development, diffusion and utilization of e-resources in engineering college libraries. Trends in Developing and Managing e-Resources in Libraries, 43-45.

Barnes, J. H. (1997). One giant leap, one small step: Continuing the migration to electronic journals. Library Trends, 45(3), 404-415.

Bennett, D. B., \& Buhler, A. G. (2010). Browsing of e-journals by engineering faculty. Issues in Science and Technology Librarianship, 61(3).

Engel, D., Robbins, S., \& Kulp, C. (2011). The information-seeking habits of engineering faculty. College \& Research Libraries, 72(6), 548-567.

Gangdhar, K. C., Nagaraja, A. N., \& Pratibha, S. N. (2012). Trends in Developing and Managing e-Resources in Libraries, 37-42.

Moghaddaszadeh, H., \& Nikam, K. (2011). Use of e-resources by the university library users of Iran and India: A Comparative study. International Journal of Information Dissemination and Technology, 1(3), 144-151.

Moghaddam, G., \& Talwar, V. G. (2008). The use of scholarly electronic journals at the Indian Institute of Science: A case study in India. Interlending \& Document Supply, 36(1), 15-29.

Parveen, N. (2012). E-Resources: An overview. Trends in Developing and Managing e-Resources in Libraries, 1-4.

Prabhushankar, M., Arokyamary, J., \& Ramasesh, C. P. (2012). Electronic resources: Utilization and the role of consortia. Trends in Developing and Managing e-Resources in Libraries, 5-11. 
Rahiman, S. A. Fazlur., \& Tamizhchelvan, M. (2011). Information seeking behavior of students of engineering colleges in and around Coimbatore: A study. European Journal of Scientific Research, 61(2), 265-272.

Rattan, G. K., \& Bala, S. (2013). Use of information resources and services at Punjabi University Extension Library, Mohali. International Journal of Information Dissemination and Technology, 3(1), 58-61.

Sudhier, K. G., \& Seethalakshmi, K. P. (2011). Use of e-resources by the students and researchers of Faculty of Arts, University of Kerala. International Journal of Information Dissemination and Technology, 1(3), 120-127.

Tucci, V. K. (2011). Assessing information-seeking behavior of computer science and engineering faculty. Issues in Science and Technology Librarianship, 64(5). Retrieved from http:// www.istl.org/11-winter/refereed5.html.

2013, July 18. Visvesvaraya Technological University, Belgaum. Retrieved from http://www.vtu. ac.in. 